\title{
Subventricular Zone-Derived Neuroblasts Migrate and Differentiate into Mature Neurons in the Post-Stroke Adult Striatum
}

\author{
Toru Yamashita, ${ }^{1,2,4,8 *}$ Mikiko Ninomiya, ${ }^{1,2,5,8 *}$ Pilar Hernández Acosta, ${ }^{6,7}{ }^{3}$ Jose Manuel García-Verdugo, ${ }^{6}$ \\ Takehiko Sunabori, ${ }^{1,2,8}$ Masanori Sakaguchi, ${ }^{2,8}$ Kazuhide Adachi, ${ }^{1,2,3,8}$ Takuro Kojima, ${ }^{1,2,8}$ Yuki Hirota, ${ }^{1,2,8}$ \\ Takeshi Kawase, ${ }^{3}$ Nobuo Araki, ${ }^{5}$ Koji Abe, ${ }^{4}$ Hideyuki Okano, ${ }^{2,8}$ and Kazunobu Sawamoto ${ }^{1,2,8}$ \\ ${ }^{1}$ Bridgestone Laboratory of Developmental and Regenerative Neurobiology and Departments of ${ }^{2}$ Physiology and ${ }^{3}$ Neurosurgery, Keio University School of \\ Medicine, Tokyo 160-8582, Japan, ${ }^{4}$ Department of Neurology, Okayama University Graduate School of Medicine, Dentistry and Pharmaceutical Sciences, \\ Okayama 700-8558, Japan, ${ }^{5}$ Department of Neurology, Saitama Medical School, Saitama 350-0495, Japan, 6University of Valencia, Valencia 46100, Spain, \\ ${ }^{7}$ Centro de Investigacion Principe Felipe, Valencia 46013, Spain, and ${ }^{8}$ Core Research for Evolutional Science and Technology, Japan Science and Technology \\ Agency, Saitama 332-0012, Japan
}

Recent studies have revealed that the adult mammalian brain has the capacity to regenerate some neurons after various insults. However, the precise mechanism of insult-induced neurogenesis has not been demonstrated. In the normal brain, GFAP-expressing cells in the subventricular zone (SVZ) of the lateral ventricles include a neurogenic cell population that gives rise to olfactory bulb neurons only. Herein, we report evidence that, after a stroke, these cells are capable of producing new neurons outside the olfactory bulbs. SVZ GFAP-expressing cells labeled by a cell-type-specific viral infection method were found to generate neuroblasts that migrated toward the injured striatum after middle cerebral artery occlusion. These neuroblasts in the striatum formed elongated chain-like cell aggregates similar to those in the normal SVZ, and these chains were observed to be closely associated with thin astrocytic processes and blood vessels. Finally, long-term tracing of the green fluorescent-labeled cells with a Cre-loxP system revealed that the SVZ-derived neuroblasts differentiated into mature neurons in the striatum, in which they expressed neuronal-specific nuclear protein and formed synapses with neighboring striatal cells. These results highlight the role of the SVZ in neuronal regeneration after a stroke and its potential as an important therapeutic target for various neurological disorders.

Key words: subventricular zone; cerebral ischemia; migration; neurogenesis; regeneration; striatum

\section{Introduction}

New neurons are continuously generated within two restricted regions of the adult mammalian brain: the subventricular zone (SVZ) of the lateral ventricle (Alvarez-Buylla and GarciaVerdugo, 2002) and the subgranular zone (SGZ) of the hippocampal dentate gyrus (Gage, 2000). In the SVZ, GFAPexpressing cells include a neurogenic cell population that gives rise to neuroblasts (Doetsch et al., 1999; Garcia et al., 2004),

Received Jan. 13, 2006; revised May 9, 2006; accepted May 13, 2006.

This work was supported by grants from Bridgestone Corporation; The Ministry of Education, Culture, Sports, Science, and Technology; The Ministry of Health, Labour, and Welfare; Mitsui Life Social Welfare Foundation; and Japan Science and Technology Agency (Core Research for Evolutional Science and Technology). We are grateful to Arturo Alvarez-Buylla, Magdalena Götz, and Tatsuhiro Hisatsune for valuable discussions; Tetsu Yoshida, Masako Katsumaru, and Mario Soriano Navarro for expert technical assistance; Noboru Sato and Hiroyuki Yaginuma for the RCAS-EGFP retrovirus vector; Izumu Saito for the AxCANCre adenovirus; Andrew D. Leavitt for the anti-TVA antibody; Jun-ichi Miyazaki for the CAG-CAT-EGFP mice; Shohei Mitani for the anti-GFP antibody; and members of our laboratories for useful advice and encouragement.

*T.Y. and M.N. contributed equally to this work.

Correspondence should be addressed to Kazunobu Sawamoto, Bridgestone Laboratory of Developmental and Regenerative Neurobiology, Keio University School of Medicine, 35 Shinanomachi, Shinjuku, Tokyo 160-8582, Japan.E-mail:sawamoto@sc.itc.keio.ac.jp.

DOI:10.1523/JNEUROSCI.0149-06.2006

Copyright $\odot 2006$ Society for Neuroscience $\quad$ 0270-6474/06/266627-10\$15.00/0 which migrate anteriorly and form an extensive network of chains (Doetsch and Alvarez-Buylla, 1996; Lois et al., 1996). Most of the neuroblasts migrate through the rostral migratory stream (RMS) into the olfactory bulb (OB), in which they differentiate into interneurons (Altman, 1969; Lois and Alvarez-Buylla, 1994; Kornack and Rakic, 2001; Pencea et al., 2001a). These interneurons in the $\mathrm{OB}$ integrate with the existing circuitry and functionally contribute to olfaction (Gheusi et al., 2000; Carleton et al., 2003). The results of in vitro studies suggest that adult human SVZ cells also have neurogenic potential (Pincus et al., 1998; Roy et al., 2000; Sanai et al., 2004). In the rodent brain, cerebral ischemia enhances neurogenesis in the SVZ and SGZ (Liu et al., 1998; Arvidsson et al., 2001; Jin et al., 2001), and ectopic neurogenesis has been observed in the ipsilateral striatum in animal models of middle cerebral artery occlusion (MCAO) (Arvidsson et al., 2002; Zhang et al., 2002) and in degenerated hippocampal CA1 (Nakatomi et al., 2002; Bendel et al., 2005) in animal models with global cerebral ischemia. These newly born neurons may compensate for the loss of neuronal function caused by strokes. A precise understanding of the mechanism of neuronal regeneration should contribute to devising novel strategies to treat patients with cerebral ischemia. 
There are two possible sources of the newly generated neurons in the ischemic striatum after MCAO. The first possible source is the SVZ, because neuroblasts born in this region have been proposed to migrate toward the striatum after ischemic injury (Arvidsson et al., 2002; Zhang et al., 2002, 2004; Jin et al., 2003). The second possible source is the striatal parenchyma, because it may also contain latent progenitor cells that can be activated and become neurogenic when stimulated by neurotrophic factors (Palmer et al., 1995; Pencea et al., 2001b). Because more specific cell labeling and tracing techniques were needed to identify the source of this ectopic neurogenesis, in this study, we performed region- and cell-type-specific cell labeling and long-term tracing experiments in combination with light and electron microscopic analyses. The results revealed the SVZ to be the principal source of the neuroblasts that form chain-like structures migrate laterally toward the injured striatal regions and differentiate into mature neurons.

\section{Materials and Methods}

Animals. Adult 9- to 16- week-old mice (20-32 g) were used in this study. Wild-type ICR mice were purchased from SLC (Shizuoka, Japan). CAGCAT-enhanced green fluorescent protein (EGFP) transgenic mice (Kawamoto et al., 2000) were provided by Dr. Jun-ichi Miyazaki (Osaka University Medical School, Suita, Osaka, Japan). GFAP tv-a (Gtv-a) transgenic mice (Holland and Varmus, 1998) were purchased from The Jackson Laboratory (Bar Harbor, ME). All animal-related procedures were approved by the Laboratory Animal Care and Use Committee of Keio University and conducted in accordance with the guidelines of the National Institutes of Health.

Focal cerebral ischemia. During surgery, the mice were anesthetized with a nitrous oxide/oxygen/isoflurane mixture (69/30/1\%) administered through an inhalation mask. Rectal temperature was maintained at $37.0^{\circ} \mathrm{C}$ by placing the animals on a heating bed (model BMT-100; Bio Research Center, Nagoya, Japan). A laser Doppler flowmeter probe (model ALF21; Advance, Tokyo, Japan) was attached to the surface of the ipsilateral cortex to monitor regional cerebral blood flow. MCAO was induced by the intraluminal filament technique reported previously (Shibata et al., 2000; Hayashi et al., 2003; Yamashita et al., 2005). In brief, the right carotid bifurcation was exposed, and the external carotid artery was coagulated distal to the bifurcation. A silicone-coated 8-0 filament was then inserted through the stump of the external cerebral artery and gently advanced $(9.0-10.0 \mathrm{~mm})$ to occlude the middle cerebral artery. After 30 min occlusion, the filament was gently withdrawn, and the incision was closed.

Adenovirus preparation and injection into the striatum. The Creencoding recombinant adenovirus AxCANCre (Kanegae et al., 1995) was kindly provided by Dr. Izumu Saito (University of Tokyo, Tokyo, Japan). Concentrated and purified virus stocks $\left(1.7 \times 10^{7}\right.$ viral particles $\left./ \mathrm{ml}\right)$ were prepared by the standard procedure as described previously (Kanegae et al., 1994). The viral suspension $(1 \mu \mathrm{l})$ was diluted in $1000 \mu \mathrm{l}$ of PBS before injection, and a $300 \mathrm{nl}$ volume of diluted viral suspension was stereotaxically injected into the striatal parenchyma [anterior, lateral, depth (in mm): 0.5, 2.0,3.0-4.0] of the CAG-CAT-EGFP transgenic mice, as shown in Figure $2 \mathrm{~A}$.

In vivo plasmid transfection of subventricular zone cells. Plasmid DNApolyethylenimine (PEI) complexes were prepared according to the instructions of the manufacturer. In short, the pxCANCre plasmid DNA $(10 \mu \mathrm{g})$ was diluted in a sterile solution of $5 \%$ glucose to a final volume of $18.8 \mu \mathrm{l}$ and complexed with $1.2 \mu \mathrm{l}$ of linear PEI (in vivo jet PEI; PolyPlus Transfection, Illkirch, France). A $2 \mu \mathrm{l}$ volume of the PEI-plasmid complexes was stereotaxically injected bilaterally into the lateral ventricle [anterior, lateral, depth (in mm): $-0.7,1.0,2.0$ ] of the CAG-CAT-EGFP transgenic mice as shown in Figure $3 A$.

Preparation and transplantation of RCAS-EGFP-virus-producing chicken fibroblasts. The plasmid for generating the replication-competent avian retrovirus RCAS-EGFP was a gift from Hiroyuki Yaginuma (Fukushima Medical University School of Medicine, Fukushima, Japan).
Chicken fibroblast cell line DF-1 (American Type Culture Collection, Manassas, VA) was transfected with the RCAS-EGFP plasmid using the FuGENE6 transfection reagent (Roche, Mannheim, Germany) as described previously (Sato et al., 2002). The virus-producing cells were washed three times with PBS to remove virus particles and pelleted by centrifugation. The pellets were resuspended in $50 \mu \mathrm{l}$ of PBS and placed on ice. A $100 \mathrm{nl}$ volume of the cell suspension $\left(3-5 \times 10^{5}\right.$ cells $)$ was stereotaxically injected into the ipsilateral striatum [anterior, lateral, depth (in mm): $0.5,2.7,3.2-4.0 ;-0.3,3.0,3.2-4.0]$ or the $\operatorname{SVZ}(0.5,1.2$, $2.0-2.5 ;-0.3,1.5,2.0-2.5$ ) (see Fig. $4 F, I$ ). GFAP-promoter-driven TVA expression in striatal astrocytes was significantly increased after MCAO (data not shown). Therefore, to label target cells at maximal efficiency, DF-1 cells were grafted at $5 \mathrm{~d}$ after MCAO (see Fig. $4 E$ ). No immunosuppressive agents were given to the animals.

Immunohistochemistry. For light microscopy, brains were fixed by perfusion with $4 \%$ paraformaldehyde, and, after postfixation overnight, 50 $\mu \mathrm{m}$ sections were cut with a vibrating blade microtome (VT1000S; Leica, Heidelberg, Germany). The following primary antibodies were used: goat anti-doublecortin (Dcx) antibody, 1:100 (Santa Cruz Biotechnology, Santa Cruz, CA); mouse anti- $\beta$ III-tubulin antibody (Tuj-1), 1:200 (Sigma, St. Louis, MO); rabbit anti-GFP antibody, 1:200 (MBL, Woburn, MA) or mouse anti-GFP antibody, 1:1000 (gift from Dr. Shohei Mitani, Tokyo Women's Medical University School of Medicine, Tokyo, Japan); mouse anti-GFAP antibody, 1:200 (Sigma); mouse anti-neuronalspecific nuclear protein (NeuN) antibody, 1:200 (Chemicon, Temecula, CA); rabbit anti-glutathione $S$-transferase (GST)- $\pi$ antibody, 1:500 (MBL); rabbit anti-TVA antibody, 1:100 (gift from Dr. Andrew D. Leavitt, University of California, San Francisco, CA); and rat anti-platelet/endothelial cell adhesion molecule-1 (PECAM-1) antibody conjugated with biotin, 1:100 (BD Biosciences PharMingen, San Diego, CA). The antibodies against Dcx, $\beta$ III-tubulin, GFP, GFAP, NeuN, GST- $\pi$, and TVA were detected with secondary antibodies conjugated with Alexa Fluor (Invitrogen, Carlsbad, CA). For detection of PECAM-1, sections were incubated with $\mathrm{ABC}$ Elite complex (Vector Laboratories, Burlingame, CA) and treated with a tyramide signal amplification kit (TSA tetramethyl rhodamine system; PerkinElmer, Boston, MA). To count Dcx-positive neuroblasts in the ischemic striatum, sections were incubated with goat anti-Dcx antibody (1:500) and then with a biotin-labeled secondary donkey anti-goat IgG antibody. After incubation with ABC Elite complex, the signal was visualized with diaminobenzidine tetrahydrochloride. Sections stained without primary antibodies showed no signals (data not shown).

For preembedding immunostaining for electron microscopy, brains were perfused with $4 \%$ paraformaldehyde and $0.1 \%$ glutaraldehyde, and, after postfixation overnight, $50 \mu \mathrm{m}$ coronal sections were cut with a vibrating blade microtome. The sections were stained with goat anti-Dcx antibody (1:100) or rabbit anti-GFP antibody (1:100) as described above.

Electron microscopic analysis. Electron microscopic analyses were performed as described previously (Doetsch et al., 1997). Briefly, the sections labeled by GFP or Dcx immunohistochemistry were postfixed in $2 \%$ osmium for $1.5 \mathrm{~h}$, incubated in $2 \%$ uranyl acetate for $2 \mathrm{~h}$, dehydrated, and embedded in Araldite (Durcupan ACM; Fluka BioChemika, Ronkonkoma, NY). To study the overall organization of the SVZ and the striatum, we cut serial $1.5 \mu \mathrm{m}$ semithin sections with a diamond knife and stained them with $1 \%$ toluidine blue. Sections containing GFPpositive cells with neuronal morphology were selected under light microscopy and used for preparation of ultrathin sections. Ultrathin $(0.05$ $\mu \mathrm{m})$ sections were cut with a diamond knife, stained with lead citrate, and examined with a Jeol (Tokyo, Japan) 1010 electron microscope.

Quantitative analysis. The Dcx-positive cells in the peri-infarct region, located in the medial half of the striatum, were counted under a microscope (Axioplan 2; Zeiss, Tokyo, Japan) in six sections from three levels of the caudate-putamen $(1.0,0.5$, and $0 \mathrm{~mm}$ rostral to the bregma) of each animal, because these sections consistently contained the infarct area in the striatum ipsilateral to the insult. To count the number of GFAP-positive cells in the GFAP/TVA double-labeled sections (see Fig. $4 A, B)$, three section levels were selected as described above, and four areas in the ipsilateral SVZ of each section were chosen randomly and captured at $100 \times$ magnification with a confocal laser microscope 
A
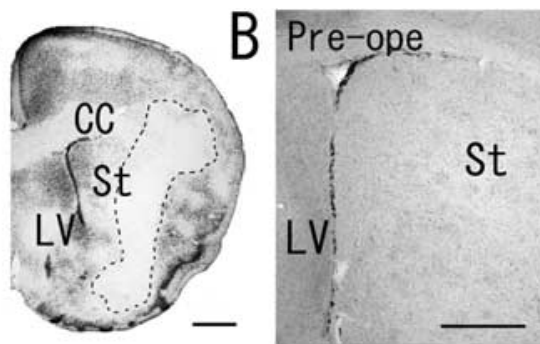

C $\frac{\text { के }}{\mathrm{\delta}}$
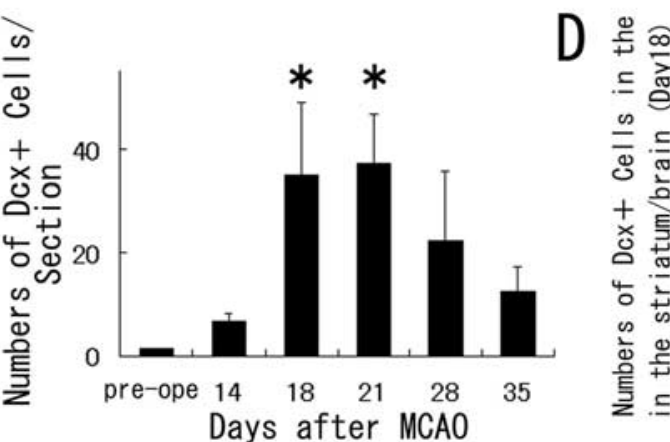

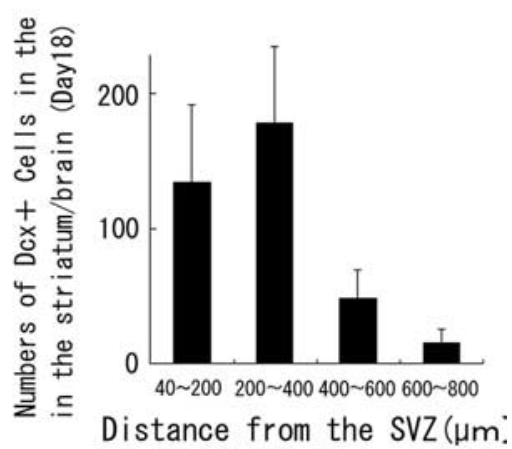

\section{Distance}
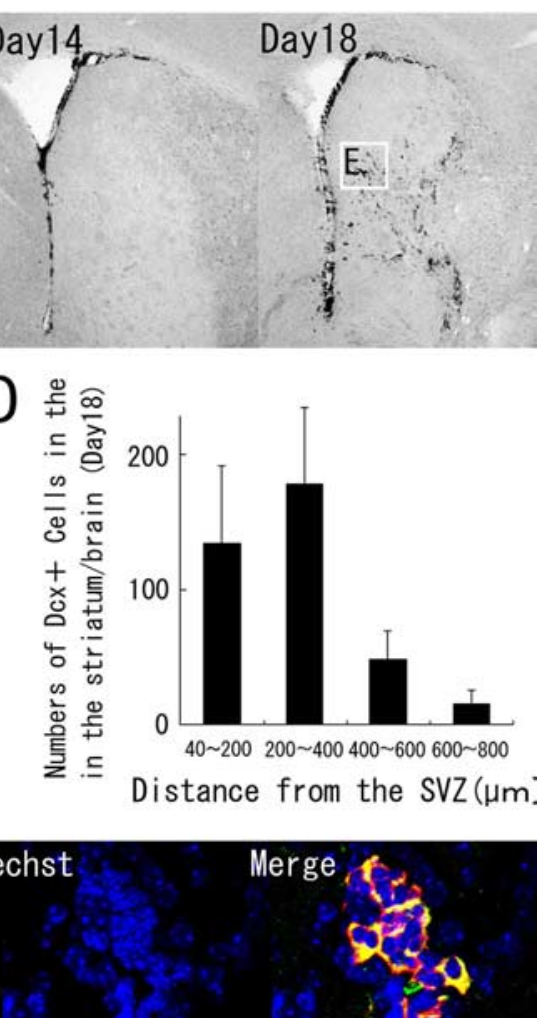

$\mathrm{E}$
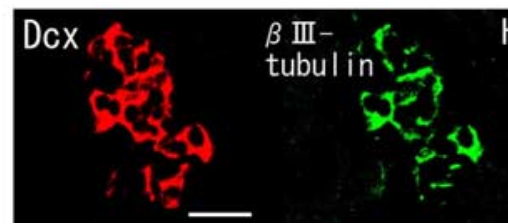

Hoechst

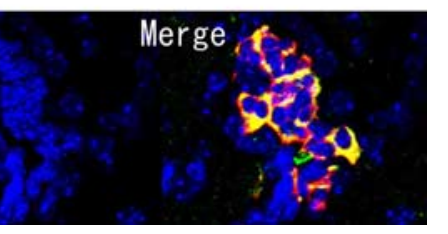

Figure 1. Neuroblasts transiently appearing in the striatum after cerebral ischemia. $\boldsymbol{A}, \mathrm{A}$ coronal brain section, obtained $14 \mathrm{~d}$ after ischemia induction and stained with cresyl violet. Dotted lines indicate the border between the intact and infarcted areas. CC, Corpus callosum; St, striatum; LV, lateral ventricle. Scale bar, $500 \mu \mathrm{m}$. B. Anti-Dcx staining of coronal brain sections obtained preoperatively (Pre-ope) and at 14 and $18 \mathrm{~d}$ after MCA0. The boxed area in $\boldsymbol{B}$ indicates the field shown in $\boldsymbol{E}$. Scale bar, $500 \mu \mathrm{m}$. $\boldsymbol{C}$, Temporal profile of Dcx-positive cells in the striata of MCAO mice ( $n=3$ at each time point). The number of Dcx-positive cells at 18 and $21 \mathrm{~d}$ after ischemia induction was significantly greater than the preoperative number. Values are means \pm SEM. ${ }^{*} p<0.01$ versus preoperative value (ANOVA, Bonferroni's correction). $D$, Numbers of Dcx-positive cells in four regions at different distances from the SVZ of brains $(n=3) 18 \mathrm{~d}$ after MCAO. $\boldsymbol{E}$, Double immunohistochemistry of the striatum with anti-Dcx antibody (red) and anti- $\beta$ III-tubulin antibody (green) $18 \mathrm{~d}$ after ischemia induction. Another neuroblast marker, $\beta$ III-tubulin, was coexpressed by $98 \%$ of the Dcx-positive cells ( $n=1108$ cells) in the striatum. Nuclear staining with Hoechst 33258 is shown in blue. Scale bar, $50 \mu \mathrm{m}$.

is mainly located in the lateral portion of the corpus striatum (Fig. $1 A$ ). As the first step in identifying the source of the neuroblasts in the ischemic striatum, we counted the number of cells expressing Dcx, a marker of neuroblasts (Brown et al., 2003; Yang et al., 2004), in the ischemic brains fixed preoperatively and at 14, 18, 21, and $35 \mathrm{~d}$ after ischemia induction (Fig. $1 B, C$ ). The numbers of Dcx-positive cells 18 and $21 \mathrm{~d}$ after ischemia induction were significantly greater than the preoperative number (Fig. 1C). Dcx-positive cells were distributed widely in the striatum at $18 \mathrm{~d}$ after MCAO (Fig. 1D), similar to results reported previously (Thored et al., 2006). Ninety-eight percent of the Dcx-positive cells ( $n=1108$ cells) found in the striatum $18 \mathrm{~d}$ after MCAO were positive for the neuronal marker $\beta$ III-tubulin (Lee et al., 1990) (Fig. 1E), indicating that they were of the neuronal and not the glial lineage. Based on this finding, we designed a series of experiments in which we performed region- and cell-type-specific labeling and tracing to identify the source of the Dcxpositive neuroblasts in the striatum (see below).

\section{Striatal cells do not generate neuroblasts}

Because of the regionally restricted emergence of neuroblasts in the striatum (Fig. 1 ), we hypothesized that striatal cells generate neuroblasts when subjected to ischemia. To test this hypothesis, we specifically labeled striatal cells and traced their fates with a Cre-loxP recombination system (Zinyk et al., 1998). We stereotaxically injected the Cre-encoding adenoviral-

(LSM510; Zeiss). For the cell-type-specific marker/GFP (see Fig. 2-6) or $\beta$ III-tubulin/Dcx (see Fig. $1 E$ ) double-labeling immunohistochemistry, confocal images were taken from four areas in the peri-infarct region of the striatum. LSM510 software was used to measure the distance between GFP/Dcx double-positive neuroblasts and the ventricular wall.

The spatial relationships between the neuroblasts and blood vessels in the striatum were studied by capturing a series of $0.8 \mu \mathrm{m}$ optical sections with a confocal laser microscope from PECAM-1/Dcx doubleimmunostained sections and reconstructing them into stacked $Z$-dimension images with Volocity software (Improvision, Lexington, MA). Based on their morphology, Dcx-positive neuroblast aggregates in the striatum were classified as either "spherical clusters" or "chains" as reported previously (Zhang et al., 2004).

Statistical analysis. Values are expressed as means \pm SEM. The differences in numbers of Dcx-positive cells in the striatum were evaluated for statistical significance by ANOVA with Bonferroni's correction. The orientation of chain-forming neuroblasts was classified as mediolateral or dorsoventral. The frequencies of chains in each orientation were compared using the $\chi^{2}$ test. Statistical significance was assumed at a $p$ value of 0.05 .

\section{Results}

Focal cerebral ischemia induces a transient increase in neuroblasts in the adult mouse striatum

In this study, we used a mouse model of middle cerebral artery occlusion (Yamashita et al., 2005), in which the infarcted region vector AxCANCre (Kanegae et al., 1995; Araki et al., 2000) into the striata of the CAG-CAT-EGFP transgenic mice, in which GFP expression is induced in Cre-introduced cells and their progeny under control of the ubiquitous CAG promoter (Kawamoto et al., 2000). Because adenoviral vectors efficiently infect most, if not all, cell types, regardless of their mitotic activity (Benihoud et al., 1999), if the Dcx-positive neuroblasts were born in the striatum, some should be labeled with GFP. The brain was examined for the presence of GFP-labeled cells after inducing MCAO (Fig. $2 A, B)$. At $5 \mathrm{~d}$ after AxCANCre injection, GFP-positive cells were present exclusively in the striatum (Fig. $2 C$ ), although none were detected around the SVZ, the other possible source of striatal neuroblasts (see below). Close examination of the sections revealed that virtually all of the cells labeled with Hoechst 33258 expressed GFP in the vicinity of the injection sites (Fig. 2D). These GFP-positive cells expressed the astrocytic marker GFAP (Fig. 2 E) (22 cells per 56 GFP-positive cells), the mature neuronal marker NeuN (Fig. $2 F$ ) (13 cells per 50 GFP-positive cells), the oligodendrocyte marker GST- $\pi$ (Hsieh et al., 2004) (Fig. 2G) (8 cells per 55 GFP-positive cells), the endothelial marker PECAM-1 (Sheibani et al., 1997) (Fig. 2H) (6 cells per 55 GFP-positive cells), or NG2, which is reportedly expressed in neuronal progenitor cells in the cortex (Dayer et al., 2005) (Fig. 2I) (8 cells per 44 
GFP-positive cells), suggesting that this method labels various types of striatal cells. We then investigated whether the GFP-positive cells in the striatum were labeled with Dcx at $18 \mathrm{~d}$ after MCAO. None of the striatal GFP-positive cells observed $(n=695)$ expressed Dcx (Fig. $2 J, K)$, suggesting the Dcx-positive neuroblasts to have been derived from brain regions outside of the striatum.

\section{SVZ cells generate neuroblasts that} migrate toward the ischemic striatum The results of previous studies have suggested the SVZ as another possible source of striatal neuroblasts (Arvidsson et al., 2002; Zhang et al., 2002, 2004; Jin et al., 2003). A specific and efficient method of labeling cells in the SVZ, a very thin cell layer lining the ventricular wall that is difficult to target, is needed to investigate whether these cells generate striatal neuroblasts. In this study, we chose intraventricular injection of plasmid DNA mixed with PEI, because it has been demonstrated to introduce foreign genes specifically into the SVZ (Lemkine et al., 2002). To verify the specificity and efficiency of this method, the Cre-encoding plasmid pxCANCre mixed with PEI was injected into the lateral ventricles of CAG-CAT-EGFP transgenic mice (Fig. 3A), and GFPpositive cells were observed in the SVZ alone at $5 \mathrm{~d}$ after the injection (Fig. 3C). We thus concluded that the Cre expression was specifically targeted to the regions close to the ventricular wall. Cell counts revealed that $50 \%$ of the GFP-expressing cells $(n=42)$ were GFAP-positive astrocytes and $6.3 \%(n=111)$ were Dcxpositive neuroblasts. Analysis of the fate of the GFP-labeled SVZ cells in the nonischemic control mice $(n=4)$ and MCAO mice $(n=6)$ on day 18 (Fig. $3 B$ ) revealed large numbers of GFP-positive cells in the $\mathrm{OB}$ and RMS of all brains in both the control group and the MCAO group (data not shown), but examination of the striatum revealed a significant difference in the distribution of GFP-positive cells between these two groups. GFP-positive cells were restricted to the SVZ in the control group, with none being observed in the striatum (Fig. 3D). In contrast, in the MCAO group, GFP-positive cells (82.0 \pm 12.1 cells per hemisphere) were found in the ipsilateral striatum (Fig. 3E), and 37\% ( $n=45$ cells) were positive for Dcx and had a long leading process (Wichterle et al., 1997), similar to that of the neuroblasts migrating in the RMS (Fig. $3 F$ ). The distribution pattern of these SVZ-derived GFP/ DCX double-immunopositive cells (Fig.

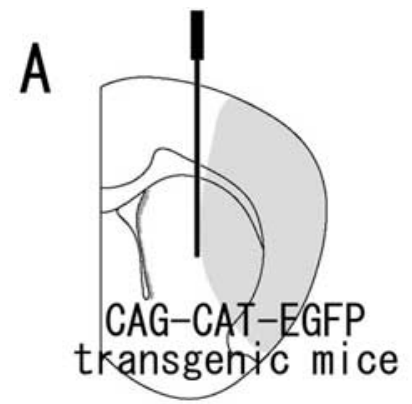

B

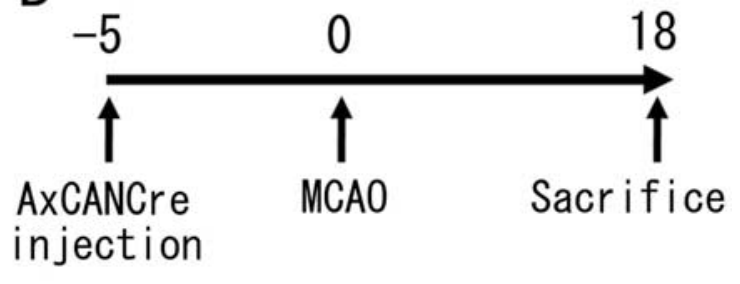

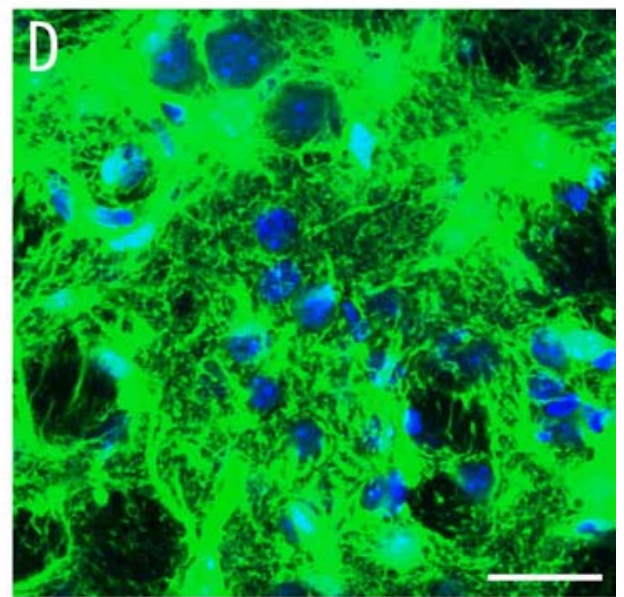
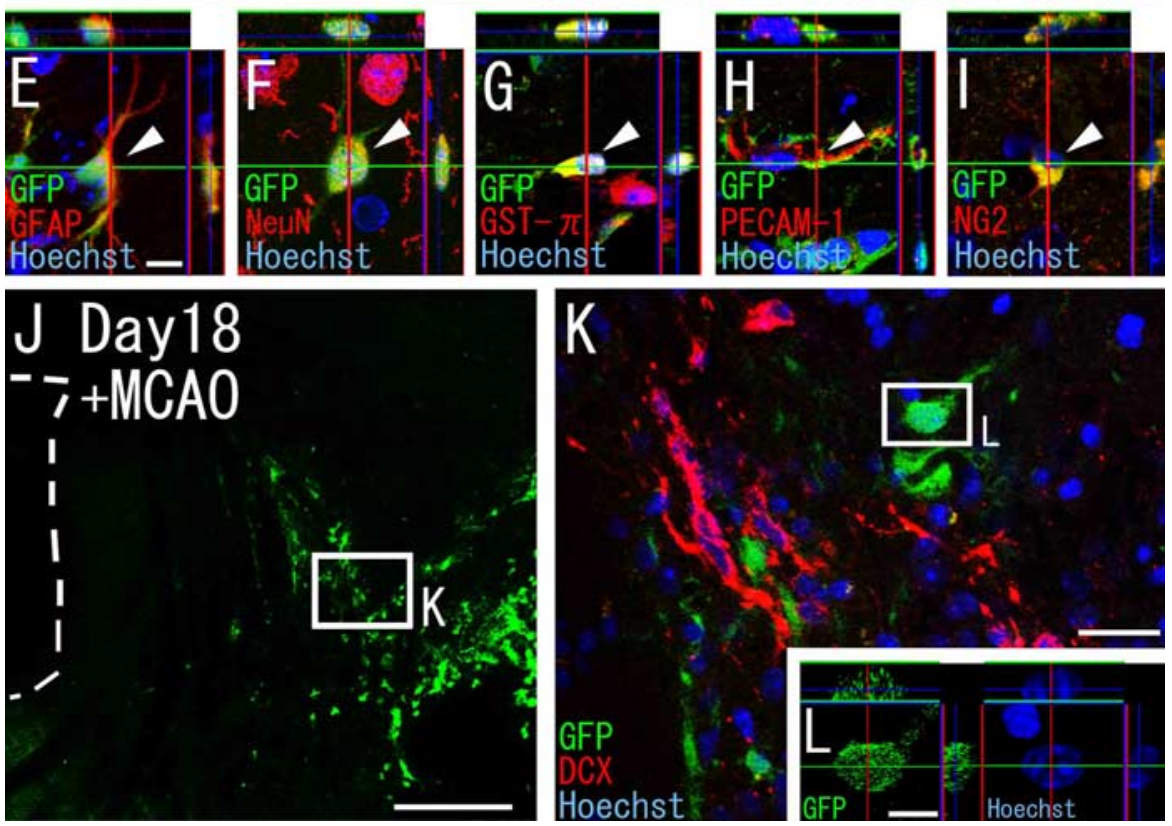

Figure 2. Striatal cells do not generate neuroblasts. $\boldsymbol{A}$, Diagram showing the injection site. AxCANCre, an adenovira vector encoding Cre recombinase under control of the CAG promoter, was injected into the striata of CAG-CAT-EGFP transgenic mice, which carry a floxed EGFP gene under control of the CAG promoter. $\boldsymbol{B}$, AxCANCre was injected $5 \mathrm{~d}$ before MCA0, and the animals were killed $18 \mathrm{~d}$ after MCA0. $\mathbf{C}-\mathbf{I}$, Expression of GFP in the striatum on day 0 ( $5 \mathrm{~d}$ after injection). C, Large numbers of GFP-positive cells (green) are present in the striatum, although there are none in the SVZ. Scale bar, $500 \mu \mathrm{m}$. LV, Lateral ventricle; St, striatum. D-I, High-power confocal images of the injection site indicated by the boxed areas in $\boldsymbol{C}$. D, All Hoechst 33258-positive cells (blue) express detectable GFP (green) in the vicinity of the injection site. Scale bar, $20 \mu \mathrm{m}$. $\boldsymbol{E}-\boldsymbol{I}$, Double stainings with cell-type-specific markers reveal that the GFP-encoding adenovirus-infected cells express GFAP $(\boldsymbol{E})$, NeuN $(\boldsymbol{F}), \mathrm{GST}-\boldsymbol{\pi}(\boldsymbol{G})$, PECAM-1 $(\boldsymbol{H})$, and NG2 $(\boldsymbol{I})$. Scale bar, $10 \mu \mathrm{m}$. Arrowheads point to GFPpositive cells colabeled with the indicated marker. $J$, Distribution of GFP-positive cells (green) in the striatum $18 \mathrm{~d}$ after MCA0. Scale bar, $500 \mu \mathrm{m}$. $\boldsymbol{K}$, High-power confocal image of the injection site indicated by the boxed area in $\boldsymbol{J}$. All GFP-labeled cells $(n=695)$ observed in three MCA0 mice are negative for Dcx. Scale bar, $20 \mu \mathrm{m}$. $L$, Orthogonal view of a GFP-positive cell indicated by the boxed area in $\boldsymbol{K}$. Among all of the GFP-positive cells analyzed $(n=62)$, each cell had an intact nucleus. Scale bar, $10 \mu \mathrm{m}$. 
A
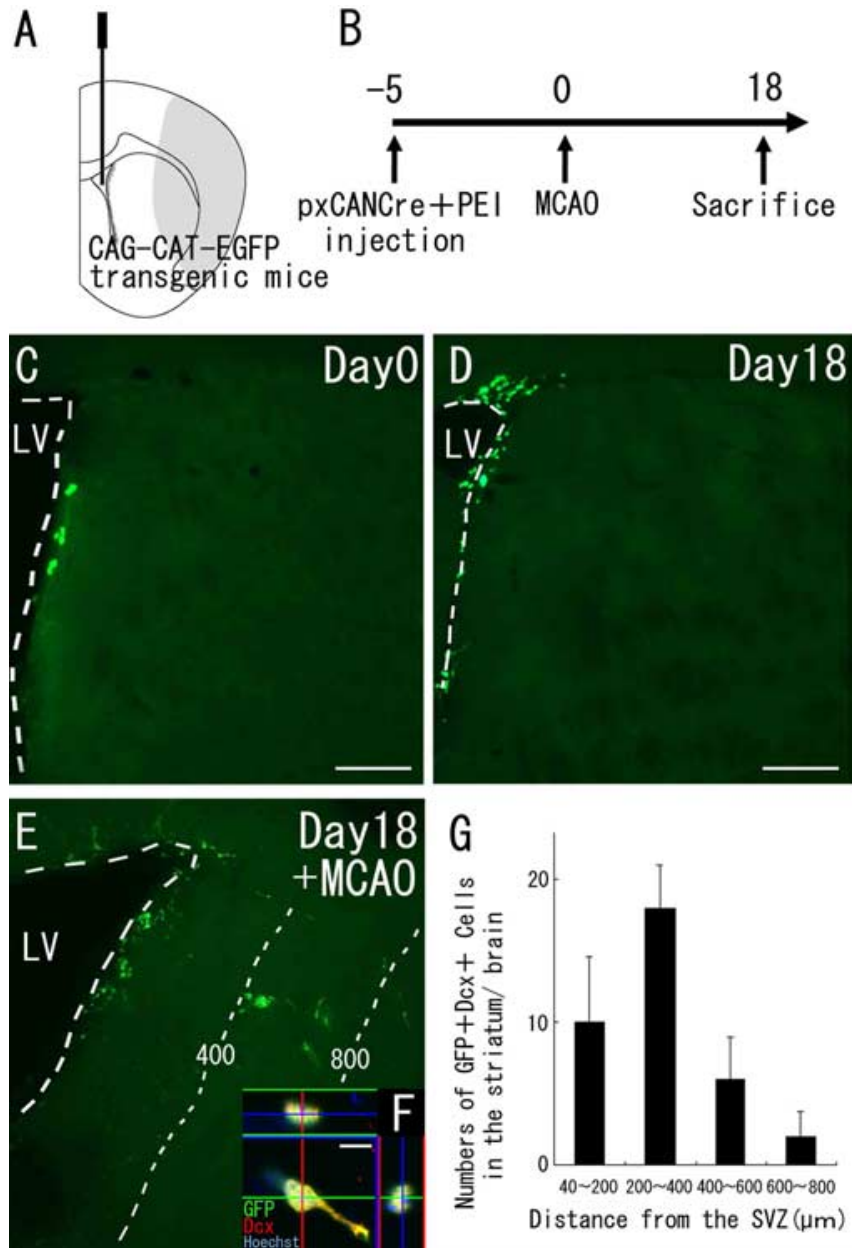

Figure 3. Neuroblasts migrate from the SVZ into the striatum after cerebral ischemia. $\boldsymbol{A}$, Diagram showing the injection site. The Cre-encoding pxCANCre plasmid was injected into the lateral ventricles of CAG-CAT-EGFP transgenic mice, which carry the floxed EGFP gene under control of the CAG promoter. $\boldsymbol{B}$, pxCANCre plasmid plus PEI was injected into the lateral ventricle $5 \mathrm{~d}$ before MCA0, and the animals were killed $18 \mathrm{~d}$ after MCAO. C, $D$, In the normal brain ( $n=4$ at each time point), GFP-positive cells (green) are observed only in the SVZ at 5 and $23 \mathrm{~d}$ after the injection (corresponding to days 0 and 18, respectively, in $\boldsymbol{B}$ ). Scale bars, $200 \mu \mathrm{m}$. $\boldsymbol{E}$, In the ischemic brain $(n=4)$, many SVZ-derived GFP-positive cells (green) are observed in the periinfarct striatum $23 \mathrm{~d}$ after the injection (corresponding to day 18 in $\boldsymbol{B}$ ). The numbers and thin dotted lines indicate distance (in micrometers) from the SVZ. $\boldsymbol{F}$, High-power confocal image of a GFP/Dcx-expressing cell exhibiting morphology typical of migrating neuroblasts. Thirty-seven percent of the GFP-positive cells $(n=45)$ in the striatum expressed Dcx. Scale bar, $10 \mu \mathrm{m} . \mathbf{G}$, Numbers of GFP/Dcx double-positive cells in four regions at different distances from the SVZ $18 \mathrm{~d}$ after MCA0. This distribution is very similar to those of GFP-positive cells (Fig. 1D). No SVZ-derived GFP/Dcx double-immunopositive cells were observed in the striatum of the nonischemic brain.

$3 G$ ) was very similar to that of DCX-positive cells (Fig. 1D). These results suggest that SVZ-derived neuroblasts migrate toward the striatal parenchyma after a stroke.

\section{SVZ GFAP-expressing cells generate striatal neuroblasts after} cerebral ischemia

Previous studies have shown that SVZ GFAP-expressing cells include a neurogenic cell population, which gives rise to neuroblasts that migrate anteriorly in the RMS and differentiate into neurons in the OB (Doetsch et al., 1999; Garcia et al., 2004; Imura et al., 2006). To determine whether SVZ GFAP-expressing cells are the source of neuroblasts in the damaged striatum, we administered the RCAS-EGFP avian retrovirus (Sato et al., 2002) into the brains of Gtv- $a$ mice, in which only GFAP-positive cells express TVA, a receptor required for infection by the avian retrovirus (Holland and Varmus, 1998; Doetsch et al., 1999; Seri et al., 2001). To confirm that TVA is specifically expressed in GFAPpositive cells in the ischemic brain, we performed double immunohistochemistry for GFAP and TVA. Confocal microscopic analyses of the SVZ tissue sections from Gtv-a transgenic mice, $8 \mathrm{~d}$ after ischemia induction, revealed that virtually all of the TVA-expressing cells were positive for GFAP (Fig. $4 A, B$ ), although the different subcellular localizations of each of the proteins did not allow quantitative analysis. In addition, all of the TVA-expressing cells $(n=327)$ were negative for Dcx (Fig. $4 C, D)$. Injection of the RCAS-EGFP virus into wild-type ischemic brains yielded no labeled cells (data not shown), indicating that infection with this virus is dependent on TVA. Thus, only GFAPpositive cells should be infected with RCAS-EGFP retrovirus even in the ischemic brain.

In this study, we transplanted the chicken fibroblast cell-line DF-1 cells producing the RCAS-EGFP virus, because it was shown to yield high virus titers at injection sites for gene transfer (Holland and Varmus, 1998). We transplanted DF-1 producing the RCAS-EGFP virus into the SVZ or the striatum of the Gtv- $a$ transgenic mice $5 \mathrm{~d}$ after MCAO and characterized the fate of GFP-positive cells $18 \mathrm{~d}$ after MCAO (Fig. $4 E$ ). Most of the GFPpositive cells in the brains, of which the striatum had been injected with RCAS-EGFP-producing cells (Fig. $4 F$ ), were still positive for GFAP (Fig. 4G), and no GFP/Dcx doubleimmunopositive cells were observed (none of 498 GFP-positive cells) (Fig. $4 \mathrm{H}$ ), consistent with the results of the adenoviral infection experiment (Fig. 2). Conversely, when cells producing the RCAS-EGFP virus were transplanted into the SVZ (Fig. 4I), all of the brains studied $(n=3)$ contained GFP/Dcx double-positive cells ( 5 cells per 13 GFP-positive cells in total) in the peri-infarct region of the striatum at $18 \mathrm{~d}$ (Fig. $4 \mathrm{~J})$. We therefore concluded that SVZ GFAP-expressing cells produce the neuroblasts observed in the ischemic striatum.

\section{Migrating neuroblasts form chain-like structures along blood} vessels in the striatum

The results described above (Figs. 2-4) indicate that most of the Dcx-positive neuroblasts migrating in the ischemic striatum originated in the SVZ. We then examined the Dcx-positive cells migrating in the striatum by immunofluorescence and electron microscopic techniques to study the morphology of the SVZderived neuroblasts in greater detail. Recent studies have found blood vessels to be involved in the regulation of neuronal progenitors in vitro or in vivo (Palmer et al., 2000; Louissaint et al., 2002; Shen et al., 2004), and insult-induced neurogenesis in the striatum is also reportedly influenced by blood vessels (Sun et al., 2003; Chen et al., 2005). Possible interactions between the migrating neuroblasts and blood vessels in the striatum were examined $18 \mathrm{~d}$ after MCAO in sections of the brain that had been stained for Dcx and PECAM-1, a marker of vascular endothelial cells (Sheibani et al., 1997). Some of the neuroblasts formed aggregates and others remained isolated in the striatum. The neuroblast aggregates were classified as spherical clusters or chains based on their morphology, as described previously (Zhang et al., 2004). All of the spherical clusters $(n=6)$ were identified at some distance from PECAM-1-positive vascular endothelial cells (Fig. $5 A)$, whereas all of the chains $(n=12)$ were wound around vascular endothelial cells (Fig. 5B,C) (supplemental movie 1, available at www.jneurosci.org as supplemental material). Most of the neuroblasts in the chain were elongated parallel to the 
A

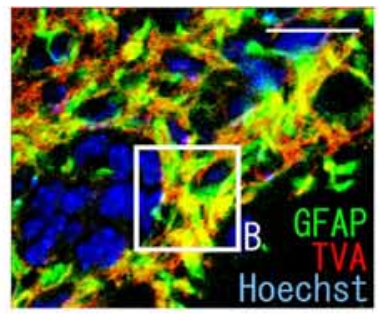

$B$

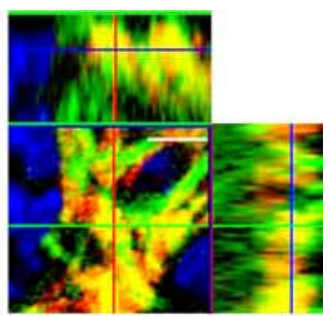

C
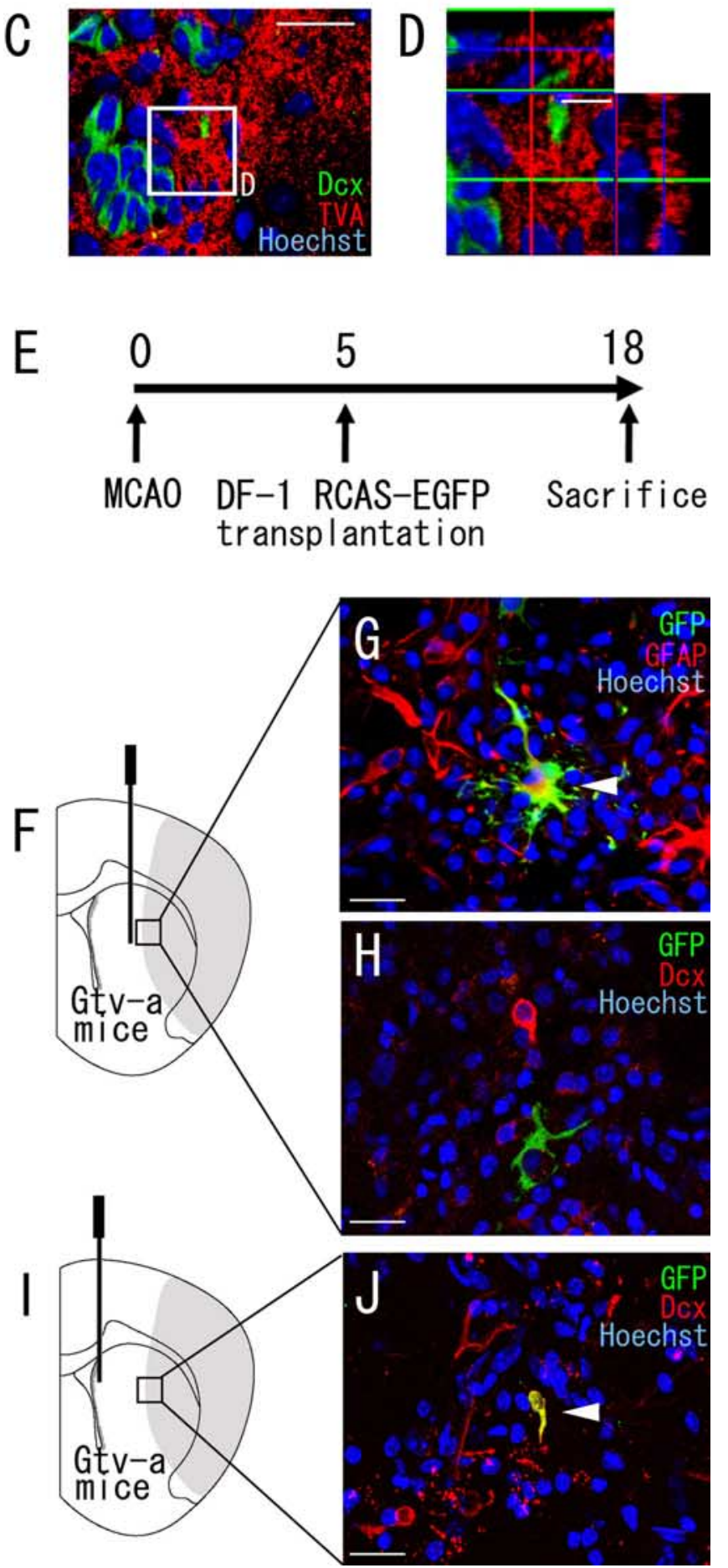

Figure 4. SVZ GFAP-expressing cells are a source of the neuroblasts that migrate into the striatum after cerebral ischemia. $\boldsymbol{A}-\boldsymbol{D}$, Double immunofluorescence of an SVZ section stained with anti-TVA antibody (red), in combination with anti-GFAP antibody (green) $(\boldsymbol{A}, \boldsymbol{B})$ or with anti-Dcx antibody (green) $(\boldsymbol{C}, \boldsymbol{D}) 8 \mathrm{~d}$ after induction of ischemia (Gtv- $a$ transgenic mice). $\boldsymbol{B}$ and blood vessels, and, interestingly, most of the chains $(83 \%, n=10)$ were oriented in the mediolateral direction (Fig. 5D-F). These findings suggest blood vessels to be involved in the chain formation and lateral migration of SVZ-derived neuroblasts toward the injured tissue. To further investigate the fine morphology of the chain structure, we examined anti-Dcx-stained sections electron microscopically. The morphology of the neuroblasts in the striatum resembled that in the intact SVZ (Doetsch et al., 1997). Their nuclei were spindle-shaped and dark, and the cytoplasm was smooth and scant (Fig. 5H). Zonula-adherens-like small junctional complexes were observed between these neuroblasts (Fig. $5 I, K)$. The chains of neuroblasts were frequently associated with thin astrocytic processes aligned close to blood vessels (Fig. $5 \mathrm{I}, \mathrm{J}$ ). Thus, the chain-like structures that developed in the striatum exhibited cellular organization and morphology similar to those of the normal SVZ.

SVZ-derived neuroblasts differentiated into mature neurons and formed synapses in the striatum

Previous studies have shown that a small population of striatal neuroblasts in the ischemic brain can survive and mature into neurons (Arvidsson et al., 2002; Teramoto et al., 2003). We tested whether SVZ-derived neuroblasts were capable of differentiating into mature neurons after prolonged survival. For this purpose, we analyzed GFP-positive cells labeled by injection of the PEIpxCANCre plasmid complex $90 \mathrm{~d}$ after MCAO (Fig. 6A, B). The results showed that a subpopulation of the GFP-positive cells ( $29 \% ; n=5$ cells) in the striatum expressed NeuN, a marker of mature neurons (Fig. 6C), and the GFP-labeled cells frequently showed a morphology typical of mature neurons (Fig. 6D). Moreover, immunoelectron microscopic examination revealed that the GFP-positive axons contained abundant presynaptic vesicles and formed synapses with neighboring cells (Fig. 6E,F). These observations indicated that SVZ-derived neuroblasts are capable of differentiating into mature neurons and being integrated into the preexisting neuronal circuit.

\section{Discussion}

SVZ GFAP-expressing cells produce neuroblasts in the peri-infarcted striatum

Migration of SVZ neuroblasts toward the injured striatum in MCAO models similar to ours has been suggested previously by the results of experiments using bromodeoxyuridine (BrdU) labeling (Arvidsson et al., 2002; Parent et al., 2002; SundholmPeters et al., 2005; Thored et al., 2006) or DiI labeling (Jin et al., 2003). Intraperitoneally administered BrdU can be incorporated into dividing cells and dying cells throughout the body (Kuan et al., 2004), such that it is not useful for determining where the cells were labeled. Because DiI is lipid soluble and transported to neighboring cells, when DiI is injected into the lateral ventricles, it labels various types of cells directly adjacent to or projecting

$\leftarrow$

$D$ show high-power views of the field indicated by the boxed areas in $A$ and $C$, respectively. Note that all of the TVA-expressing cells contain detectable signals of GFAP but not DCX. B, D, $10 \mu \mathrm{m}$. $\boldsymbol{E}$, DF-1 cells transfected with the RCAS-EGFP plasmid were transplanted into the striatum $(\boldsymbol{F}-\boldsymbol{H})$ or SVZ $(\boldsymbol{I}, \boldsymbol{J}) 5 \mathrm{~d}$ after MCAO, and the animals were killed $18 \mathrm{~d}$ after MCAO. $\boldsymbol{F}-\boldsymbol{H}$, In the brains $(n=16)$ in which RCAS-EGFP-producing DF-1 cells were transplanted into the striatum $(\boldsymbol{F})$, GFP/GFAP double-positive cells were frequently observed $(\boldsymbol{G})$. However, all GFP ${ }^{+}$cells examined $(n=498)$ were negative for $D c x(\boldsymbol{H})$. Scale bar, $20 \mu \mathrm{m}$. $\boldsymbol{I}, \boldsymbol{J}$, All brains $(n=3)$ in which RCAS-EGFP-producing DF-1 cells were transplanted into the SVZ (I) contained GFP/DCx double-positive cells (5 cells per 13 GFP-positive cells in total) in the peri-infarct region of the striatum at $18 \mathrm{~d}(J)$. Scale bar, $20 \mu \mathrm{m}$. 

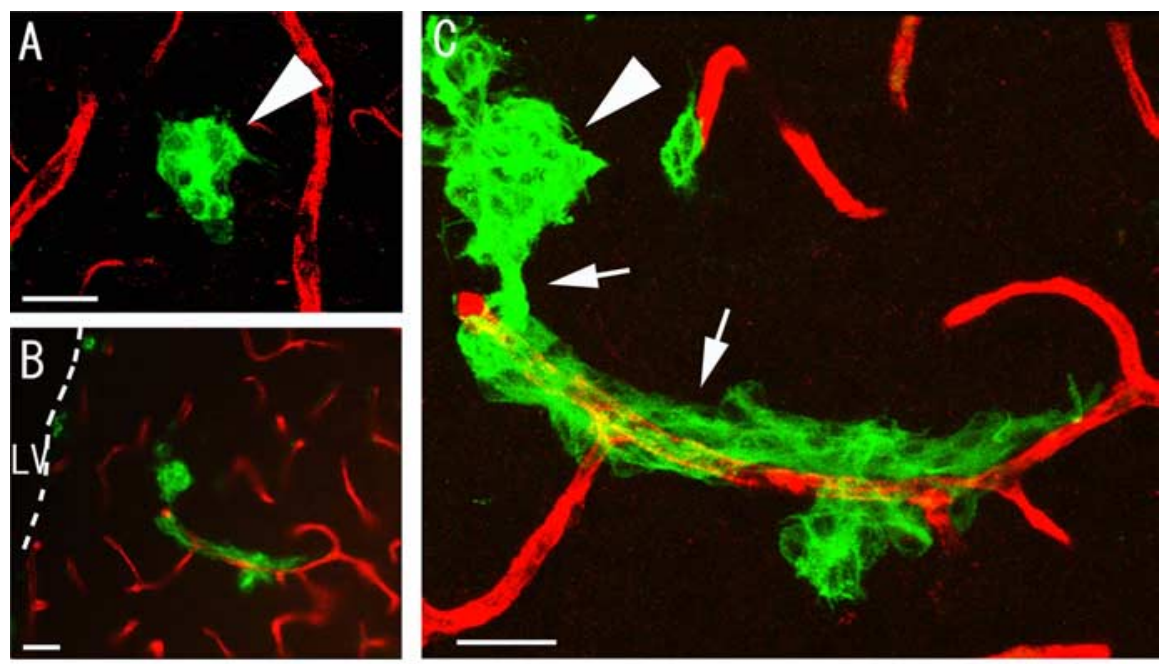

D
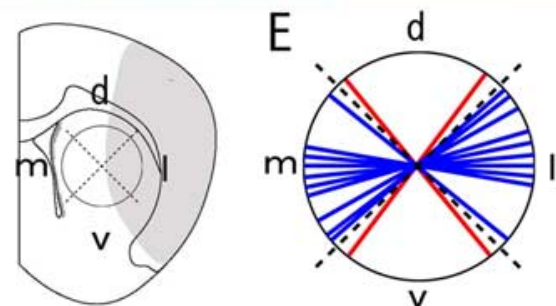

$\mathrm{F}$
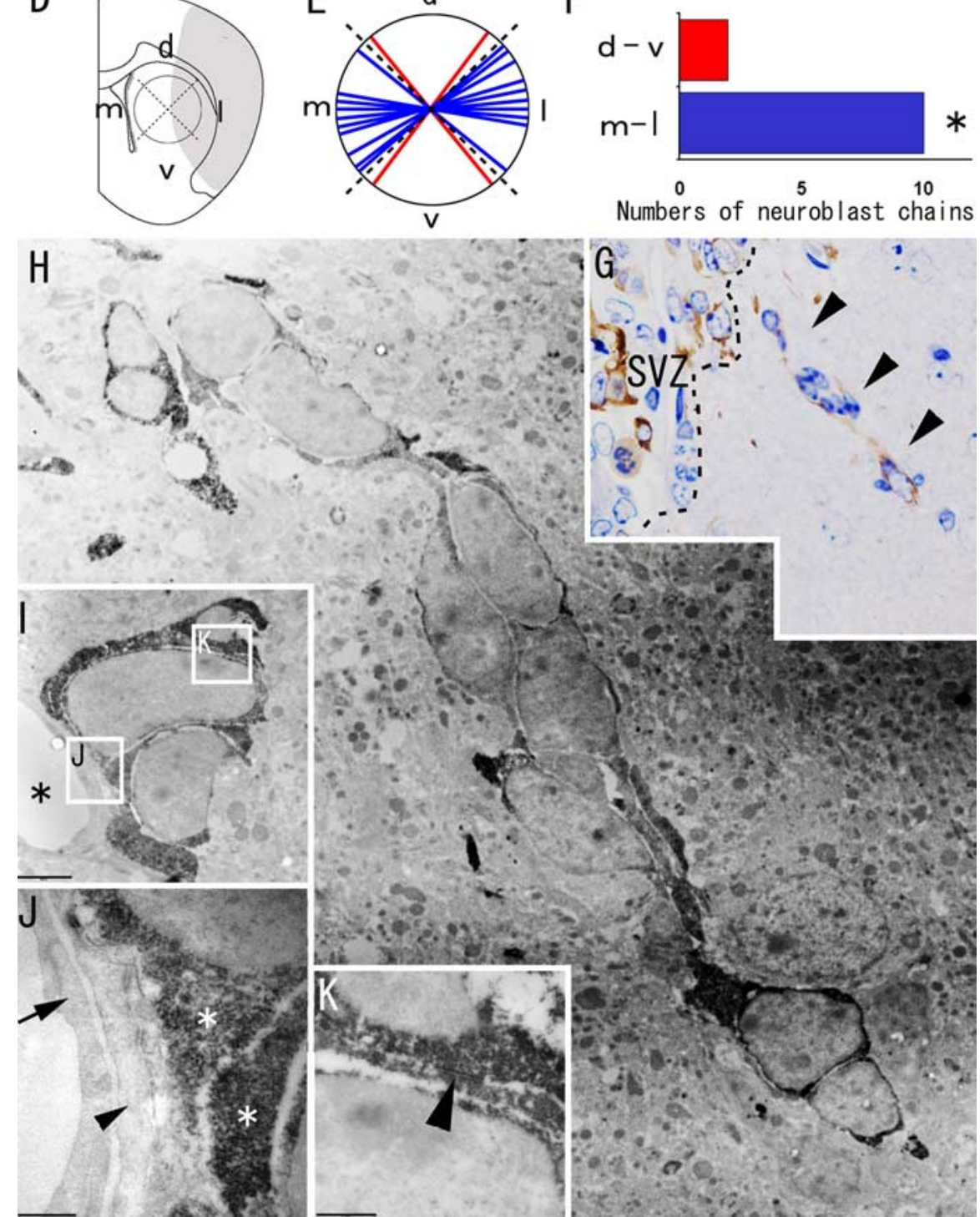

Figure 5. Migrating neuroblasts formed elongated aggregates associated with blood vessels in the ischemic striatum. $\boldsymbol{A}-\boldsymbol{C}$, Double immunohistochemistry of the striatum with anti-PECAM-1 antibody (red) and anti-Dcx antibody (green) $18 \mathrm{~d}$ after ischemia induction. $A$, Spherical clusters of Dcx-positive neuroblasts $(n=6)$ are at some distance from the PECAM-1-positive vascular endothelial cells. $\boldsymbol{B}, \boldsymbol{C}$, Chains of neuroblasts $(n=12)$ wind around the vascular endothelial cells. Note that this chain appears to extend toward the injured region (on the right, in this figure) and to be connected with a spherical cluster of neuroblasts that is not associated with blood vessels. See also supplemental movie 1 (available at www.jneurosci.org as supplemental into the ventricular wall independently of cell migration (Frielingsdorf et al., 2004). Both BrdU and DiI are diluted by cell divisions, which makes it difficult to study the phenotypes of the matured progeny of labeled cells after a long period. Moreover, the SVZ is a very thin cell layer lining the ventricular wall and is difficult to specifically target by stereotaxic viral injections. To overcome these technical limitations, we injected Cre-encoding plasmid into the lateral ventricles of transgenic mice carrying a floxed GFP gene, which made it possible to specifically label SVZ cells and trace their progeny until $90 \mathrm{~d}$ after MCAO. The results of our experiments provide direct evidence that the SVZ is the principal source of the neuroblasts that migrate into the ischemic striatum and differentiate into mature neurons. We also performed cell-type-specific labeling by the RCASTVA system (Bell and Brickell, 1997), which has been used to study the fate of GFAP-expressing cells in vivo (Holland and Varmus, 1998; Doetsch et al., 1999; Seri et al., 2001). The results of previous studies indicate that SVZ GFAPexpressing cells generate only olfactory bulb neurons in the normal brain (Doetsch et al., 1999), whereas the results of our study strongly suggest that SVZ GFAP-expressing cells give rise to neuroblasts that migrate into the injured striatum. However, because we could not directly show that the cells originally infected with the RCAS-EGFP virus were actually expressing GFAP, we cannot rule out the possibility that other cell types in the SVZ generated the EGFP-positive neu-

\section{$\leftarrow$}

material). Arrowheads, Spherical cluster of neuroblasts; arrows, elongated chain-like aggregate of neuroblasts. LV, Lateral ventricle. Scale bars, $20 \mu \mathrm{m}$. D, The chains were classified on the basis of their dorsoventral $(\mathrm{d}-\mathrm{v})$ and mediolateral (m-l) orientations. d, Dorsal; v, ventral; m, medial; l, lateral. $\boldsymbol{E}$, $\boldsymbol{F}$, The number of mediolaterally oriented chain-like neuroblasts (blue) was significantly larger than the number of dorsoventrally oriented neuroblasts (red). ${ }^{*} p<0.05$ ( $\chi^{2}$ test). $\mathbf{G}, \mathbf{D}(x-$-stained semithin section of the striatum. The ectopic chain of neuroblasts in the electron micrograph in $\boldsymbol{H}$ is marked by arrowheads. $\boldsymbol{H}-\boldsymbol{K}$, Electron microscopic view of neuroblasts migrating within the striatum. $\boldsymbol{H}$, Each Dcxpositive cell contains abundant lax chromatin, two to four small nucleoli, and a smooth scant cytoplasm, similar to neuroblasts in the SVZ. I, Dcx-positive neuroblasts are located close to blood vessels. Asterisks, Blood vessels. The boxed areas in $\boldsymbol{I}$ indicate the fields shown in $\boldsymbol{J}$ and $\boldsymbol{K}$. Scale bar, 2 $\mu \mathrm{m} . J, \mathrm{Dcx}$-positive neuroblasts are adjacent to the thin processes of astrocytes (arrowhead) associated with endothelial cells (arrow) of blood vessels. Asterisks, Cytoplasm of Dcxpositive neuroblasts. Scale bar, $500 \mathrm{~nm}$. $\boldsymbol{K}$, A zonulaadherens-like contact (arrowhead) is observed between two Dcx-positive neuroblasts. Scale bar, $500 \mathrm{~nm}$. 

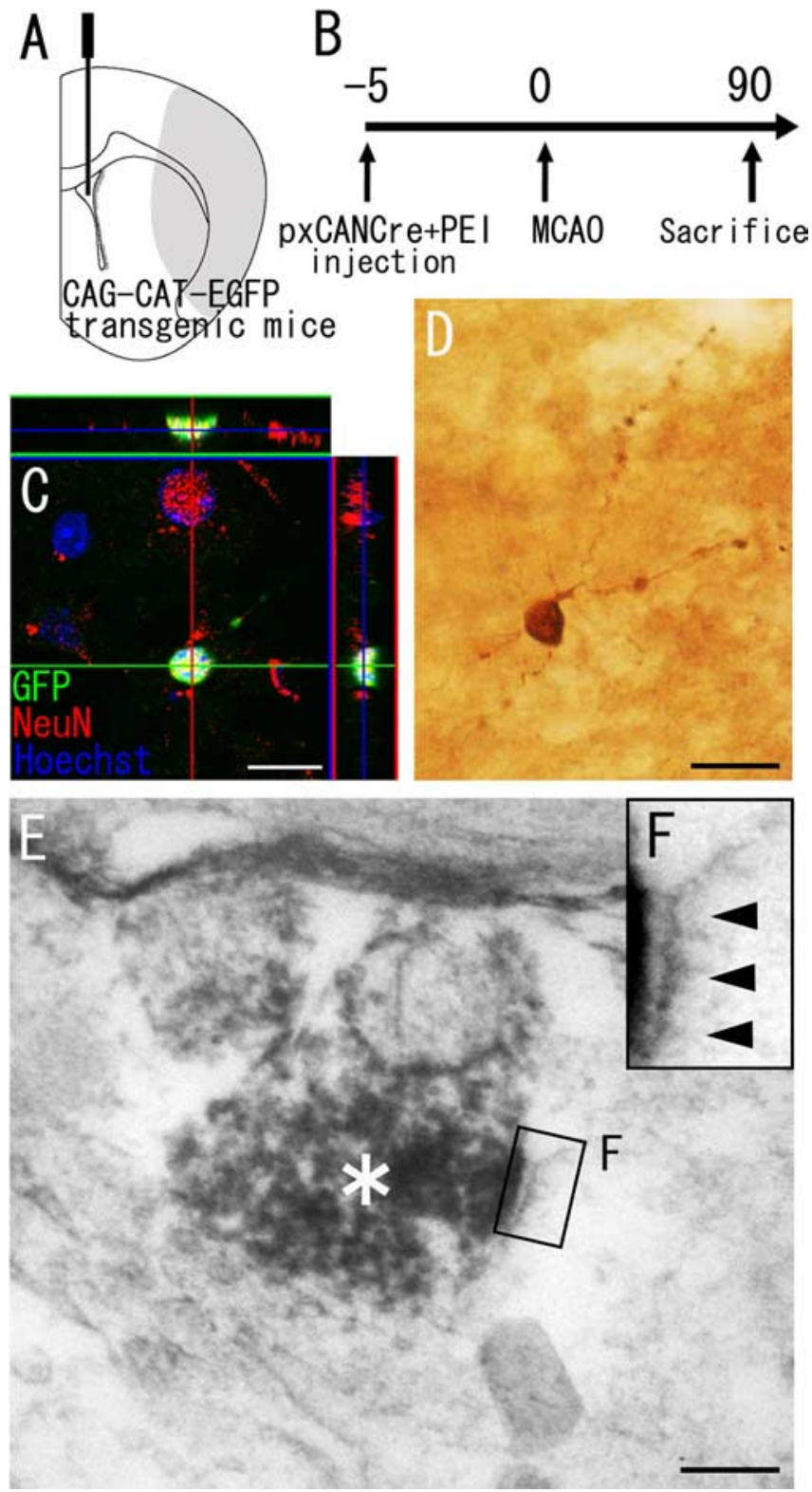

Figure 6. SVZ-derived neuroblasts differentiate into mature neurons and form synapses in the striatum by $90 \mathrm{~d}$ after MCAO. $\boldsymbol{A}$, Diagram showing the injection site. $\boldsymbol{B}$, The pxCANCre plasmid was injected into the lateral ventricle $5 \mathrm{~d}$ before $\mathrm{MCA0}$, and the animals were killed $90 \mathrm{~d}$ after MCAO. C, Confocal three-dimensional reconstruction image of a GFP/NeuN doublepositive cell. At $90 \mathrm{~d}$ after MCA0, 29\% of the SVZ-derived GFP-positive cells $(n=13)$ in the striatum expressed NeuN, a specific marker for mature neurons. Scale bar, $20 \mu \mathrm{m}$. D, A GFPpositive cell exhibiting neuronal morphology. Scale bar, $20 \mu \mathrm{m}$. $\boldsymbol{E}$, An electron micrograph showing a GFP-positive axon (asterisk) containing presynaptic vesicles. Scale bar, $0.5 \mu \mathrm{m} . \boldsymbol{F}$, High-power magnification view of the region indicated by the boxed area in $\boldsymbol{E}$. The postsynaptic density is indicated by arrowheads.

roblasts. Interestingly, SVZ cells have been implicated in the generation of glial cells in the mechanically injured cerebral cortex (Goings et al., 2004) and the corpus callosum damaged by experimental autoimmune encephalomyelitis (Picard-Riera et al., 2002). Thus, it is possible that SVZ GFAP-expressing cells generate various types of progenitors, which have the ability to migrate to diverse damaged brain regions and replace the various types of cells lost by brain injury or brain disease.
Striatal cells do not generate neuroblasts in the ischemic brain

The results of this study suggest neuroblasts appearing in the peri-infarcted striatum to be derived from brain regions outside of the striatum (Fig. 2), and this finding is consistent with the idea that the distribution of the neurogenic cell population is restricted to a niche in which a special microenvironment supports their survival and function in the adult brain (Herrera et al., 1999; Shihabuddin et al., 2000). However, we were unable to rule out the possibility that the striatum contains a population of rare neurogenic cells undetectable under our experimental conditions. Previous in vitro studies have revealed that cells isolated from the striatum can generate new neurons when stimulated by intrinsic or extrinsic factors (Palmer et al., 1995; Wang et al., 2004), suggesting that latent neural progenitor cells reside in the striatal parenchyma. These latent neural progenitor cells may be activated by manipulating the signaling pathways that determine their cell fate. Noggin, an antagonist for bone morphogenetic protein, has been reported to promote neuronal differentiation of stem cells (Lim et al., 2000). Moreover, forced expression of Pax6 (paired box gene 6) (Heins et al., 2002) and a dominantnegative Olig2 (oligodendrocyte lineage transcription factor 2) mutant (Buffo et al., 2005) induce neurogenesis in the cortex. These factors may be useful for activating the neurogenic potential of progenitor cells in the striatal parenchyma.

\section{Neuroblasts emigrate from the SVZ into the injured region}

The present results show that neuroblasts that migrate into the ischemic striatum form elongated aggregates that are morphologically similar to those in the SVZ, as reported previously in rats (Zhang et al., 2004). The chain-like structures were observed to be in contact with thin processes of astrocytes in the striatum, similar to those in the RMS (Lois et al., 1996) and SVZ (Doetsch et al., 1997). Astrocyte-derived migration-inducing activity has been reported to stimulate chain migration by neuroblasts in vitro (Mason et al., 2001) and may be involved in the lateral chain migration in the ischemic striatum as well.

Our SVZ-specific labeling experiments using a Cre-loxP system provided direct evidence that a subpopulation of SVZ neuroblasts, which migrate anteriorly in the normal brain, are laterally redirected to the injured striatum. There are two possible mechanisms to explain the ischemia-induced change in the $\mathrm{di}-$ rection of neuroblast migration. First, ischemia may disrupt mechanisms that restrict neuroblasts within the SVZ. Second, ischemia may promote lateral migration by neuroblasts through altered expression of guidance molecules, such as Slit proteins, which determine the direction of neuroblast migration in the SVZ as repellents (Wu et al., 1999; Sawamoto et al., 2006). Chemotactic cytokines, such as stromal cell-derived factor $1 \mathrm{a}$, expressed in the injured striatum may also be involved in this process (Robin et al., 2006; Thored et al., 2006). Our results demonstrate that SVZ-derived neuroblasts directionally migrate in chain-like structures parallel to blood vessels toward the infarcted region. Blood vessels in the damaged striatum may play a crucial role in the migration and/or survival of these neuroblasts, perhaps by releasing diffusible factors, such as BDNF (Louissaint et al., 2002).

\section{SVZ cells generate mature neurons in the striatum}

Previous reports have described BrdU-labeled newborn cells as expressing markers for mature neurons within the damaged striatum as early as $30 \mathrm{~d}$ after the induction of ischemia (Arvidsson et al., 2002; Parent et al., 2002). In the present study, we examined 
the phenotype of SVZ-derived GFP-labeled cells by light and electron microscopy after an extended survival period ( $90 \mathrm{~d})$. The labeled cells were found to possess long processes, express NeuN, and form synaptic structures in the damaged striatum $90 \mathrm{~d}$ after ischemia induction. These results strongly suggest SVZ cells to have the ability to generate functional mature neurons that survive in the damaged striatum for considerable periods.

Based on all of the results of this study, we conclude that SVZ is the main source of the neuroblasts that migrate toward the brain region infarcted by cerebral ischemia, in which they differentiate into mature neurons. Our findings indicate that, as an important endogenous cell source, SVZ is a promising therapeutic target for various neurological disorders. However, it remains unclear what types of neurons are generated, although some of the SVZ-derived neurons showed a dopaminergic phenotype (our unpublished observation). In addition, the number of newborn neurons is too small for recovery of neurological functions (Arvidsson et al., 2002). Thus, it will be necessary to add appropriate interventions to enhance the proliferation, survival, and/or neuronal maturation of SVZ cells and their progeny. The mechanisms of insult-induced neurogenesis described herein are anticipated to be of fundamental importance to studying molecular mechanisms that control SVZ cells and their progeny and for developing novel neuronal self-repair strategies.

\section{References}

Altman J (1969) Autoradiographic and histological studies of postnatal neurogenesis. IV. Cell proliferation and migration in the anterior forebrain, with special reference to persisting neurogenesis in the olfactory bulb. J Comp Neurol 137:433-457.

Alvarez-Buylla A, Garcia-Verdugo JM (2002) Neurogenesis in adult subventricular zone. J Neurosci 22:629-634.

Araki T, Shibata M, Takano R, Hisahara S, Imamura S, Fukuuchi Y, Saruta T, Okano H, Miura M (2000) Conditional expression of anti-apoptotic protein $\mathrm{p} 35$ by Cre-mediated DNA recombination in cardiomyocytes from loxP-p35-transgenic mice. Cell Death Differ 7:485-492.

Arvidsson A, Kokaia Z, Lindvall O (2001) N-methyl-D-aspartate receptormediated increase of neurogenesis in adult rat dentate gyrus following stroke. Eur J Neurosci 14:10-18.

Arvidsson A, Collin T, Kirik D, Kokaia Z, Lindvall O (2002) Neuronal replacement from endogenous precursors in the adult brain after stroke. Nat Med 8:963-970.

Bell EJ, Brickell PM (1997) Replication-competent retroviral vectors for expressing genes in avian cells in vitro and in vivo. Mol Biotechnol 7:289-298

Bendel O, Bueters T, von Euler M, Ove Ogren S, Sandin J, von Euler G (2005) Reappearance of hippocampal CA1 neurons after ischemia is associated with recovery of learning and memory. J Cereb Blood Flow Metab 25:1586-1595.

Benihoud K, Yeh P, Perricaudet M (1999) Adenovirus vectors for gene delivery. Curr Opin Biotechnol 10:440-447.

Brown JP, Couillard-Despres S, Cooper-Kuhn CM, Winkler J, Aigner L, Kuhn HG (2003) Transient expression of doublecortin during adult neurogenesis. J Comp Neurol 467:1-10.

Buffo A, Vosko MR, Erturk D, Hamann GF, Jucker M, Rowitch D, Gotz M (2005) Expression pattern of the transcription factor Olig2 in response to brain injuries: Implications for neuronal repair. Proc Natl Acad Sci USA 102:18183-18188.

Carleton A, Petreanu LT, Lansford R, Alvarez-Buylla A, Lledo PM (2003) Becoming a new neuron in the adult olfactory bulb. Nat Neurosci 6:507-518.

Chen J, Zacharek A, Zhang C, Jiang H, Li Y, Roberts C, Lu M, Kapke A, Chopp M (2005) Endothelial nitric oxide synthase regulates brain-derived neurotrophic factor expression and neurogenesis after stroke in mice. J Neurosci 25:2366-2375.

Dayer AG, Cleaver KM, Abouantoun T, Cameron HA (2005) New GABAergic interneurons in the adult neocortex and striatum are generated from different precursors. J Cell Biol 168:415-427.

Doetsch F, Alvarez-Buylla A (1996) Network of tangential pathways for neuronal migration in adult mammalian brain. Proc Natl Acad Sci USA 93:14895-14900.

Doetsch F, Garcia-Verdugo JM, Alvarez-Buylla A (1997) Cellular composition and three-dimensional organization of the subventricular germinal zone in the adult mammalian brain. J Neurosci 17:5046-5061.

Doetsch F, Caille I, Lim DA, Garcia-Verdugo JM, Alvarez-Buylla A (1999) Subventricular zone astrocytes are neural stem cells in the adult mammalian brain. Cell 97:703-716.

Frielingsdorf H, Schwarz K, Brundin P, Mohapel P (2004) No evidence for new dopaminergic neurons in the adult mammalian substantia nigra. Proc Natl Acad Sci USA 101:10177-10182.

Gage FH (2000) Mammalian neural stem cells. Science 287:1433-1438.

Garcia AD, Doan NB, Imura T, Bush TG, Sofroniew MV (2004) GFAPexpressing progenitors are the principal source of constitutive neurogenesis in adult mouse forebrain. Nat Neurosci 7:1233-1241.

Gheusi G, Cremer H, McLean H, Chazal G, Vincent JD, Lledo PM (2000) Importance of newly generated neurons in the adult olfactory bulb for odor discrimination. Proc Natl Acad Sci USA 97:1823-1828.

Goings GE, Sahni V, Szele FG (2004) Migration patterns of subventricular zone cells in adult mice change after cerebral cortex injury. Brain Res 996:213-226.

Hayashi T, Noshita N, Sugawara T, Chan PH (2003) Temporal profile of angiogenesis and expression of related genes in the brain after ischemia. J Cereb Blood Flow Metab 23:166-180.

Heins N, Malatesta P, Cecconi F, Nakafuku M, Tucker KL, Hack MA, Chapouton P, Barde YA, Gotz M (2002) Glial cells generate neurons: the role of the transcription factor Pax6. Nat Neurosci 5:308-315.

Herrera DG, Garcia-Verdugo JM, Alvarez-Buylla A (1999) Adult-derived neural precursors transplanted into multiple regions in the adult brain. Ann Neurol 46:867-877.

Holland EC, Varmus HE (1998) Basic fibroblast growth factor induces cell migration and proliferation after glia-specific gene transfer in mice. Proc Natl Acad Sci USA 95:1218-1223.

Hsieh J, Aimone JB, Kaspar BK, Kuwabara T, Nakashima K, Gage FH (2004) IGF-I instructs multipotent adult neural progenitor cells to become oligodendrocytes. J Cell Biol 164:111-122.

Imura T, Nakano I, Kornblum HI, Sofroniew MV (2006) Phenotypic and functional heterogeneity of GFAP-expressing cells in vitro: differential expression of LeX/CD15 by GFAP-expressing multipotent neural stem cells and non-neurogenic astrocytes. Glia 53:277-293.

Jin K, Minami M, Lan JQ, Mao XO, Batteur S, Simon RP, Greenberg DA (2001) Neurogenesis in dentate subgranular zone and rostral subventricular zone after focal cerebral ischemia in the rat. Proc Natl Acad Sci USA 98:4710-4715.

Jin K, Sun Y, Xie L, Peel A, Mao XO, Batteur S, Greenberg DA (2003) Directed migration of neuronal precursors into the ischemic cerebral cortex and striatum. Mol Cell Neurosci 24:171-189.

Kanegae Y, Makimura M, Saito I (1994) A simple and efficient method for purification of infectious recombinant adenovirus. Jpn J Med Sci Biol 47:157-166.

Kanegae Y, Lee G, Sato Y, Tanaka M, Nakai M, Sakaki T, Sugano S, Saito I (1995) Efficient gene activation in mammalian cells by using recombinant adenovirus expressing site-specific Cre recombinase. Nucleic Acids Res 23:3816-3821.

Kawamoto S, Niwa H, Tashiro F, Sano S, Kondoh G, Takeda J, Tabayashi K, Miyazaki J (2000) A novel reporter mouse strain that expresses enhanced green fluorescent protein upon Cre-mediated recombination. FEBS Lett 470:263-268.

Kornack DR, Rakic P (2001) The generation, migration, and differentiation of olfactory neurons in the adult primate brain. Proc Natl Acad Sci USA 98:4752-4757.

Kuan CY, Schloemer AJ, Lu A, Burns KA, Weng WL, Williams MT, Strauss KI, Vorhees CV, Flavell RA, Davis RJ, Sharp FR, Rakic P (2004) Hypoxia-ischemia induces DNA synthesis without cell proliferation in dying neurons in adult rodent brain. J Neurosci 24:10763-10772.

Lee MK, Tuttle JB, Rebhun LI, Cleveland DW, Frankfurter A (1990) The expression and posttranslational modification of a neuron-specific betatubulin isotype during chick embryogenesis. Cell Motil Cytoskeleton 17:118-132.

Lemkine GF, Mantero S, Migne C, Raji A, Goula D, Normandie P, Levi G, Demeneix BA (2002) Preferential transfection of adult mouse neural 
stem cells and their immediate progeny in vivo with polyethylenimine. Mol Cell Neurosci 19:165-174.

Lim DA, Tramontin AD, Trevejo JM, Herrera DG, Garcia-Verdugo JM, Alvarez-Buylla A (2000) Noggin antagonizes BMP signaling to create a niche for adult neurogenesis. Neuron 28:713-726.

Liu J, Solway K, Messing RO, Sharp FR (1998) Increased neurogenesis in the dentate gyrus after transient global ischemia in gerbils. J Neurosci 18:7768-7778.

Lois C, Alvarez-Buylla A (1994) Long-distance neuronal migration in the adult mammalian brain. Science 264:1145-1148.

Lois C, Garcia-Verdugo JM, Alvarez-Buylla A (1996) Chain migration of neuronal precursors. Science 271:978-981.

Louissaint Jr A, Rao S, Leventhal C, Goldman SA (2002) Coordinated interaction of neurogenesis and angiogenesis in the adult songbird brain. Neuron 34:945-960.

Mason HA, Ito S, Corfas G (2001) Extracellular signals that regulate the tangential migration of olfactory bulb neuronal precursors: inducers, inhibitors, and repellents. J Neurosci 21:7654-7663.

Nakatomi H, Kuriu T, Okabe S, Yamamoto S, Hatano O, Kawahara N, Tamura A, Kirino T, Nakafuku M (2002) Regeneration of hippocampal pyramidal neurons after ischemic brain injury by recruitment of endogenous neural progenitors. Cell 110:429-441.

Palmer TD, Ray J, Gage FH (1995) FGF-2-responsive neuronal progenitors reside in proliferative and quiescent regions of the adult rodent brain. $\mathrm{Mol}$ Cell Neurosci 6:474-486.

Palmer TD, Willhoite AR, Gage FH (2000) Vascular niche for adult hippocampal neurogenesis. J Comp Neurol 425:479-494.

Parent JM, Vexler ZS, Gong C, Derugin N, Ferriero DM (2002) Rat forebrain neurogenesis and striatal neuron replacement after focal stroke. Ann Neurol 52:802-813.

Pencea V, Bingaman KD, Freedman LJ, Luskin MB (2001a) Neurogenesis in the subventricular zone and rostral migratory stream of the neonatal and adult primate forebrain. Exp Neurol 172:1-16.

Pencea V, Bingaman KD, Wiegand SJ, Luskin MB (2001b) Infusion of brain-derived neurotrophic factor into the lateral ventricle of the adult rat leads to new neurons in the parenchyma of the striatum, septum, thalamus, and hypothalamus. J Neurosci 21:6706-6717.

Picard-Riera N, Decker L, Delarasse C, Goude K, Nait-Oumesmar B, Liblau R, Pham-Dinh D, Evercooren AB (2002) Experimental autoimmune encephalomyelitis mobilizes neural progenitors from the subventricular zone to undergo oligodendrogenesis in adult mice. Proc Natl Acad Sci USA 99:13211-13216.

Pincus DW, Keyoung HM, Harrison-Restelli C, Goodman RR, Fraser RA, Edgar M, Sakakibara S, Okano H, Nedergaard M, Goldman SA (1998) Fibroblast growth factor-2/brain-derived neurotrophic factor-associated maturation of new neurons generated from adult human subependymal cells. Ann Neurol 43:576-585.

Robin AM, Zhang ZG, Wang L, Zhang RL, Katakowski M, Zhang L, Wang Y, Zhang C, Chopp M (2006) Stromal cell-derived factor 1alpha mediates neural progenitor cell motility after focal cerebral ischemia. J Cereb Blood Flow Metab 26:125-134.

Roy NS, Benraiss A, Wang S, Fraser RA, Goodman R, Couldwell WT, Nedergaard M, Kawaguchi A, Okano H, Goldman SA (2000) Promotertargeted selection and isolation of neural progenitor cells from the adult human ventricular zone. J Neurosci Res 59:321-331.

Sanai N, Tramontin AD, Quinones-Hinojosa A, Barbaro NM, Gupta N, Kunwar S, Lawton MT, McDermott MW, Parsa AT, Manuel-Garcia Verdugo J, Berger MS, Alvarez-Buylla A (2004) Unique astrocyte ribbon in adult human brain contains neural stem cells but lacks chain migration. Nature 427:740-744.

Sato N, Matsuda K, Sakuma C, Foster DN, Oppenheim RW, Yaginuma H
(2002) Regulated gene expression in the chicken embryo by using replication-competent retroviral vectors. J Virol 76:1980-1985.

Sawamoto K, Wichterle H, Gonzalez-Perez O, Cholfin JA, Yamada M, Spassky N, Murcia NS, Garcia-Verdugo JM, Marin O, Rubenstein JL, Tessier-Lavigne M, Okano H, Alvarez-Buylla A (2006) New neurons follow the flow of cerebrospinal fluid in the adult brain. Science 311:629-632.

Seri B, Garcia-Verdugo JM, McEwen BS, Alvarez-Buylla A (2001) Astrocytes give rise to new neurons in the adult mammalian hippocampus. J Neurosci 21:7153-7160.

Sheibani N, Newman PJ, Frazier WA (1997) Thrombospondin-1, a natural inhibitor of angiogenesis, regulates platelet-endothelial cell adhesion molecule-1 expression and endothelial cell morphogenesis. Mol Biol Cell 8:1329-1341.

Shen Q, Goderie SK, Jin L, Karanth N, Sun Y, Abramova N, Vincent P, Pumiglia K, Temple S (2004) Endothelial cells stimulate self-renewal and expand neurogenesis of neural stem cells. Science 304:1338-1340.

Shibata M, Hisahara S, Hara H, Yamawaki T, Fukuuchi Y, Yuan J, Okano H, Miura M (2000) Caspases determine the vulnerability of oligodendrocytes in the ischemic brain. J Clin Invest 106:643-653.

Shihabuddin LS, Horner PJ, Ray J, Gage FH (2000) Adult spinal cord stem cells generate neurons after transplantation in the adult dentate gyrus. J Neurosci 20:8727-8735.

Sun Y, Jin K, Xie L, Childs J, Mao XO, Logvinova A, Greenberg DA (2003) VEGF-induced neuroprotection, neurogenesis, and angiogenesis after focal cerebral ischemia. J Clin Invest 111:1843-1851.

Sundholm-Peters NL, Yang HK, Goings GE, Walker AS, Szele FG (2005) Subventricular zone neuroblasts emigrate toward cortical lesions. J Neuropathol Exp Neurol 64:1089-1100.

Teramoto T, Qiu J, Plumier JC, Moskowitz MA (2003) EGF amplifies the replacement of parvalbumin-expressing striatal interneurons after ischemia. J Clin Invest 111:1125-1132.

Thored P, Arvidsson A, Cacci E, Ahlenius H, Kallur T, Darsalia V, Ekdahl CT, Kokaia Z, Lindvall O (2006) Persistent production of neurons from adult brain stem cells during recovery after stroke. Stem Cells 24:739-747.

Wang K, Wang JJ, Wang Y, He QH, Wang X, Wang XM (2004) Infusion of epidermal growth factor and basic fibroblast growth factor into the striatum of parkinsonian rats leads to in vitro proliferation and differentiation of adult neural progenitor cells. Neurosci Lett 364:154-158.

Wichterle H, Garcia-Verdugo JM, Alvarez-Buylla A (1997) Direct evidence for homotypic, glia-independent neuronal migration. Neuron 18:779-791.

Wu W, Wong K, Chen J, Jiang Z, Dupuis S, Wu JY, Rao Y (1999) Directional guidance of neuronal migration in the olfactory system by the protein Slit. Nature 400:331-336.

Yamashita T, Sawamoto K, Suzuki S, Suzuki N, Adachi K, Kawase T, Mihara M, Ohsugi Y, Abe K, Okano H (2005) Blockade of interleukin-6 signaling aggravates ischemic cerebral damage in mice: possible involvement of Stat3 activation in the protection of neurons. J Neurochem 94:459-468.

Yang HK, Sundholm-Peters NL, Goings GE, Walker AS, Hyland K, Szele FG (2004) Distribution of doublecortin expressing cells near the lateral ventricles in the adult mouse brain. J Neurosci Res 76:282-295.

Zhang R, Wang Y, Zhang L, Zhang Z, Tsang W, Lu M, Zhang L, Chopp M (2002) Sildenafil (Viagra) induces neurogenesis and promotes functional recovery after stroke in rats. Stroke 33:2675-2680.

Zhang R, Zhang Z, Wang L, Wang Y, Gousev A, Zhang L, Ho KL, Morshead C, Chopp M (2004) Activated neural stem cells contribute to strokeinduced neurogenesis and neuroblast migration toward the infarct boundary in adult rats. J Cereb Blood Flow Metab 24:441-448.

Zinyk DL, Mercer EH, Harris E, Anderson DJ, Joyner AL (1998) Fate mapping of the mouse midbrain-hindbrain constriction using a site-specific recombination system. Curr Biol 8:665-668. 